\title{
111. 那覇市の密集市街地における避難路の改善可能性の検討
}

Possibility of evacuation routes improvement in densely built-up area in Naha

清水 肇*・松島 啓信 $* *$

Hajime Shimizu*, Hironobu Matsushima**

\begin{abstract}
Densely built-up areas in Okinawa have problems of evacuation routes because of narrow alleys network in blocks. This study aims to examine the possibility to improve evacuation routes in densely built-up area in Naha city.

Examined measures for improvement are "agreement of evacuation in emergency", "open space for evacuation" and "rebuilding with evacuation space". Indexes to assess evacuation routes are "width of routes", "existence of wooden building along routes" and "two way evacuation routes".

Simulation shows improvements of "width of routes" and "existence of wooden building" are little and "two way evacuation routes" are improved by the measures. Potential of improvement by "agreement of evacuation in emergency" is relatively higher than other two measures and it is effective to combine three measures.
\end{abstract}

keywords: densely built-up area, evacuation route, alley, area improvement 密集市街地, 避難路, 細街路, 地区の改善

\section{1.はじめに}

狭险道路、狭小敷地と老朽化が進行する住宅が集中する 密集市街地は、防災、住環境、居住の継承に関わる複合的 な課題を抱えており、様々な改善方法が検討されてきた。 面的に基盤を更新する改造的方法が適用される一方で、小 規模で持続的な改善型まちづくりの検討と実践も重ねられ ている。改善型まちづくりとしては、基盤施設の小規模な 改善、個別更新や共同化の誘導と促進、避難経路の改善な どが検討され実践例がある。

密集市街地改善に関する研究の中で、近年、小規模で持 続的な改善を扱ったものとしては、個別更新の可能性を探 究した金子他（2017）1）をはじめとする国土技術政策総 合研究所の一連の研究や、鶴谷・赤崎（2010） 2）の自律 更新のスタディがある。これらは木造住宅密集地を対象と して、火災に関わる防災性能と建築更新の関係を検討して いる。建築基準法上の接道問題を抱える敷地の建築更新を 進めつつ、建築の不燃性・耐火性の向上、避難経路を改善 する可能性を探っている。木造住宅密集地においては、高 い火災リスクの中での避難性能の検証が重要な焦点となっ ている。

沖縄の密集市街地については、加島・小野3) が那覇市 の密集市街地の形成過程と実態についての詳細な整理を 行っている。同論文によれば、密集市街地を多く含む真和 志地区においても木造建物棟数率は多くとも $30 \%$ 程度で ある一方、接道不良建物割合は 50 ～70\%程度の地区が多い。 密集市街地の基盤条件のもとでコンクリート造住宅への建 替が進んだ状況においては「国の密集市街地改善のための 整備事業を適用できない。沖縄の密集市街地の実状に即し た事業の創設が必要である。と指摘している。木造住宅 が比較的少ない密集市街地においては、東京、大阪等を対
象とした既往の研究・実践とは異なった改善方法の検討が 必要と考えられる。

加島・小野 ${ }^{3)}$ は、地区ごとの特性に即して面的整備や 建替推進等を含む改善方向全般に言及しているが、本研究 は特に狭险な道路・通路が入り組む地域において、避難 路の状態を早期に改善することを現実的な検討課題として 設定する。避難路の改善だけでは密集市街地の防災・住環 境問題を根本的に解決するものではないが、現状の市街地 空間の条件を可能な限り活用して地域の安全性を高める一 つの方法であり、地域住民やコミュニティの取り組みにあ たっても現実的な目標として設定できるものである。

避難路の状況の改善を検討するにあたり、平常時に一般 の通行に供されている既存の避難路に加えて、災害等の緊 急時に避難や救助に使用可能となる経路（以下、緊急避難 路）を確保することを含めた方法と地域の空地等を活用す る防災空地を組み合わせた改善方法を検討する。

避難経路を扱った研究では、一時避難場所に至るやや広 い範囲の避難経路を扱った研究が多い中で、飯島・真野 （2009） 4）は住宅から街路に出るまでの街区内避難経路を 扱っている。緊急避難路については櫻井・宇於㠃（2014）5） の板橋区の取り組みについての報告がある。三好他 (2017) 6) は神戸市の「まちなか防災空地整備事業」を扱い、防 災空地の一部が通路化されて避難路形成に貢献する場合が ある等を明らかにしている。本研究はこれらの成果を参照 しつつ、これまで検討されていない既存避難路、緊急避難 路、防災空地の組合せを検討することに特色がある。

\section{2. 研究の目的と方法}

本研究の目的は以下のとおりである。 (1)那覇市の密集市街地の中で調査対象地区を選定し、避難

* 正会員 琉球大学工学部建築学コース (University of the Ryukyus)

** 正会員 那覇市役所建築指導課 (Naha City Government) 
路に関わる道路・通路、土地利用と建物の実態を把握する。 (2)調査対象地区における避難路の実態評価を行う。

(3)避難路の状況を改善する手法を設定し、改善手法による 避難路の状況の変化の可能性を検討し、改善手法の効果の 可能性を明らかにする。

研究の対象は沖縄島中南部各地に分布する密集市街地の 中で面的にもつとも大きな広がりを持つ那覇市真和志地区 の中で「那覇市密集住宅市街地再生方針」(1) の「再生重 点地区」の住宅密集市街地から対象地区を選定した。

加島・小野 $\left.{ }^{3}\right)$ は、那覇市の密集市街地を 5 種の類型で 説明している。この類型は避難路に関わる課題を抽出する 上で有効であり、5 類型の中で避難路に関わる課題が多い と考えられる(A未接道（未接道敷地が密集）、B袋小路（袋 小路の 2 項道路が集中)、 ( $\mathrm{E}$ 道路ネット不良（幅 $4 \mathrm{~m}$ 以上の 道路の袋小路が集中）の多い地域として、(A)の多い松 川 2 丁目（以下［松 2 ])、(A)の多い三原 2 丁目（[三 2 ] ) (E)の多い繁多川2丁目（[繁 2]）を選定した（図 1)。

密集市街地の街区内の建物から一時避難場所までの避難 経路を考えると、建物から幅員の広い公道へ至るまでが避 難・救助上の困難が特に生じ得る区間である。以下、本研 究で言う避難路は、各建物から幅員 $4 \mathrm{~m}$ 以上、かつ二方向 へ通じた道路へ到達するまでの経路を指すこととする。

避難を想定する前提となる災害は、震度 5 弱程度の地震 とそれに伴う火災または単発の火災とする。多数の建物が 倒壊する程度の地震の場合に対してはインフラ、建築の両 面での根本的な対策が必要と考えられるが、より発生確率 の高い災害に対する避難路の改善を本研究では検討する。

3 地区の避難路に関わる状況を評価する指標として、(1) 避難路の幅員、(2)避難路沿いの木造建物の有無、(3)二方向 避難路の有無の 3 つを設定した（4章）。

3 地区について緊急避難路の改善のための手法として、 (1)緊急避難路利用協定、(2)防災空地整備、(3)緊急避難路形 成型協調建替の 3 つの手法を設定し（５章）、設定による 改善の可能性を検討した ( 6 章)。

以上をもとに那覇市の密集市街地における避難路の改善 の可能性について考察を行った ( 7 章)。

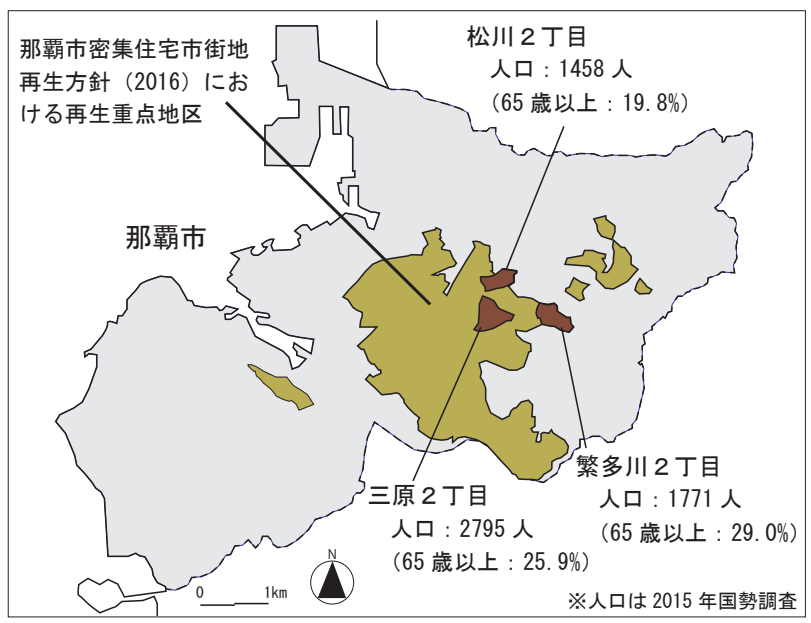

図 1 研究対象の 3 地区

\section{3. 調査対象地区の状況}

調査対象地区の状況を資料と現地観察調査によって確認 した（図 2 )。

地区の道路・通路のネットワークについては ${ }^{(2)}$ 、[松 2 ] [三2］は二項道路と非道路が不規則に街区内を巡る形と なっている。[繁 2］は幅員 $4 \mathrm{~m}$ 以上の位置指定道路が多 数であり、一般的な密集市街地と異なる面があるが、非道 路と二項道路に沿った小さな住宅密集地を袋小路の位置指 定道路からなる住宅地が囲んでおり避難路について問題を 抱えた地区であることがわかる。

木造建物の割合（棟数）は［松 2] 24.9\%、[三 2] $36.7 \%$ 、[繁 2］18.8\%であり、特に［三2］の街区内の 数力所に古い木造住宅が集中している。街区を越えて延焼 する大火災の可能性は日本の大都市の木造密集市街地に比 ベて低いと考えられるが、地区の一部に火災リスクの高い 場所がある。

近年の変化をとらえるため、空地等（駐車場、畑、荒地、 用途不明の空地) の 1995 年と 2017 年の状況を比較した (図 3) (3)

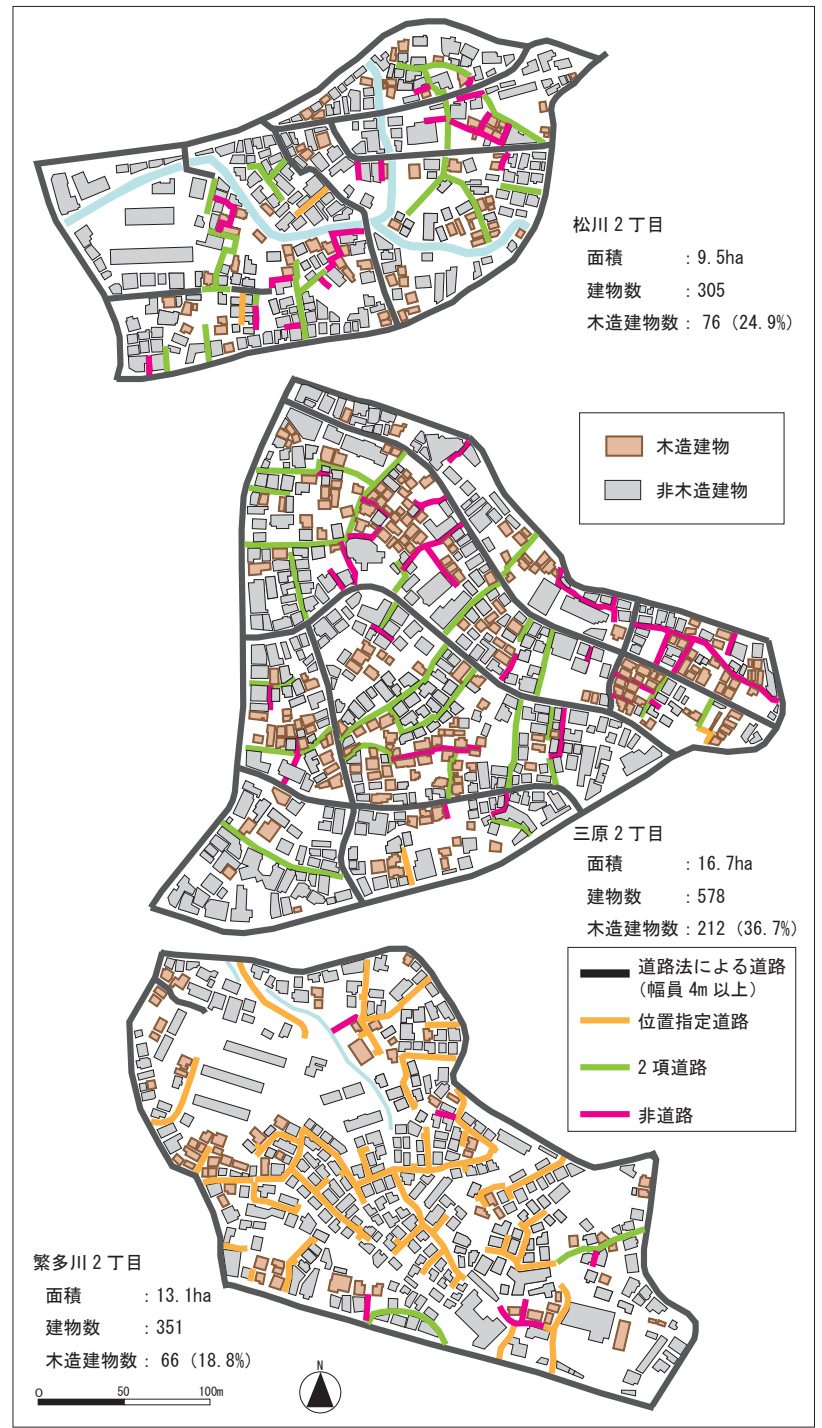

図 2 道路種別、木造・非木造建物の状況 
空地等は、3 地区とも増加しており、とくに [三 2 ］は 4 倍以上に増え街区の内側の荒地が目立つ状況が生じてい る。1995 年の空地等の一部には 2017 年までに建物が建て られており、空地等の位置は流動的である。新築数よりも 除却数が多いために空地等が増加している。

\section{4. 避難路の評価指標と三地区の避難路の状況}

本研究では、個々の建物（3 地区計 1232） から幅員 4 $\mathrm{m}$ 以上で 2 方向以上に通じた道路に至る避難路の全てにつ いて、個別に地図上の検討および現地確認の上で書き出し、 個々の建物利用者にとっての避難路の総体として地区の避 難路をとらえていく。

個々の避難路の状況を評価する指標を検討した。

飯島・真野（2009） 4）は避難にあたっての通路に対し て主として幅員で評価し、さらに二方向避難の可能性にも 触れている。本研究では沖縄の密集市街地の特性を踏まえ て以下の 3 つの指標を設定した。

評価指標 1 - 避難路幅員（以下、幅員）: 本研究の対象 地区では、とくに［松 2］と［三 3 ］に幅 $2 \mathrm{~m}$ 以下の狭小 な避難路が多数いりくんで存在する。幅員の狭さは沖縄の 市街地全般に広くみられるブロック塀の問題にも関連す る。ブロック塀は避難路沿いに多く設置されているが、そ れらの多くが耐震性能に問題があることが指摘されている 7)。幅 $2 \mathrm{~m}$ 程度以下の通路は地震時のブロック塀の倒壊に よる閉塞の可能性が高い。各建物からの避難路の最狭部の 幅を評価指標 1 とする。

評価指標 2 ・避難路沿いの木造建物の有無（以下、木造・ 非木造）: 非木造建物が多い沖縄の密集市街地においては、 火災時において避難経路沿いに木造建物がなく火災時のリ
スクの低い避難路が存在する。各建物からの避難路につい て、避難路沿いの木造建物の有無を評価指標 2 とする。

評価指標 3 -二方向避難路（以下、二方向）: 閉塞や火 災に対して二方向以上の避難路が確保できればリスクを軽 減できる。建物からの二方向以上の避難路の有無を評価指 標 3 と寸る。建物を出た場所から二方向が確保されている ことが条件であり、途中で枝分かれして二方向避難路があ るものは二方向避難路確保には含まない。

三地区の避難路の現状について建物ごとの状況を集計し た（図 5 の「現状」）。

避難路の幅員については、[三2］で 51.1\%、[松 2］で $37.8 \%$ の建物の避難路の最狭部幅員が $4 \mathrm{~m}$ 未満である。[繁 2］は位置指定道路が多いために避難路幅はやや広いもの が多い。

避難路沿いに木造建物がある件数は、「松 2 ］33\%、[三 2 ] 33. 1\%、[繁 2]21.7\% である。

二方向に避難路がない建物件数は、「松 2］28.9\%、[三 2 ] 23. 7\%、[繁 2］39.3 である。[繁 2］は比較的幅員が広く 非木造建物が多い一方で袋小路が多いために割合が高い。

\section{5．避難路の改善手法の設定}

地区の避難路の改善可能性を検討寸るにあたり、地域住 民組織による緊急避難路づくりのための「路地普請」の取 り組み (5)、那覇市での住民ワークショップをもとにした 筆者（2018）の検討 ${ }^{8)}$ 、および、市町村の先駆的な事業、 制度の取り組みを参照し、既存の民有地を活用して避難路 を改善する手法を 3 つ設定した。手法 1 と 2 は現在の空間 を活用する方法、手法 3 は今後の建築活動にともなう改善 を想定するものである（図 4 ）。

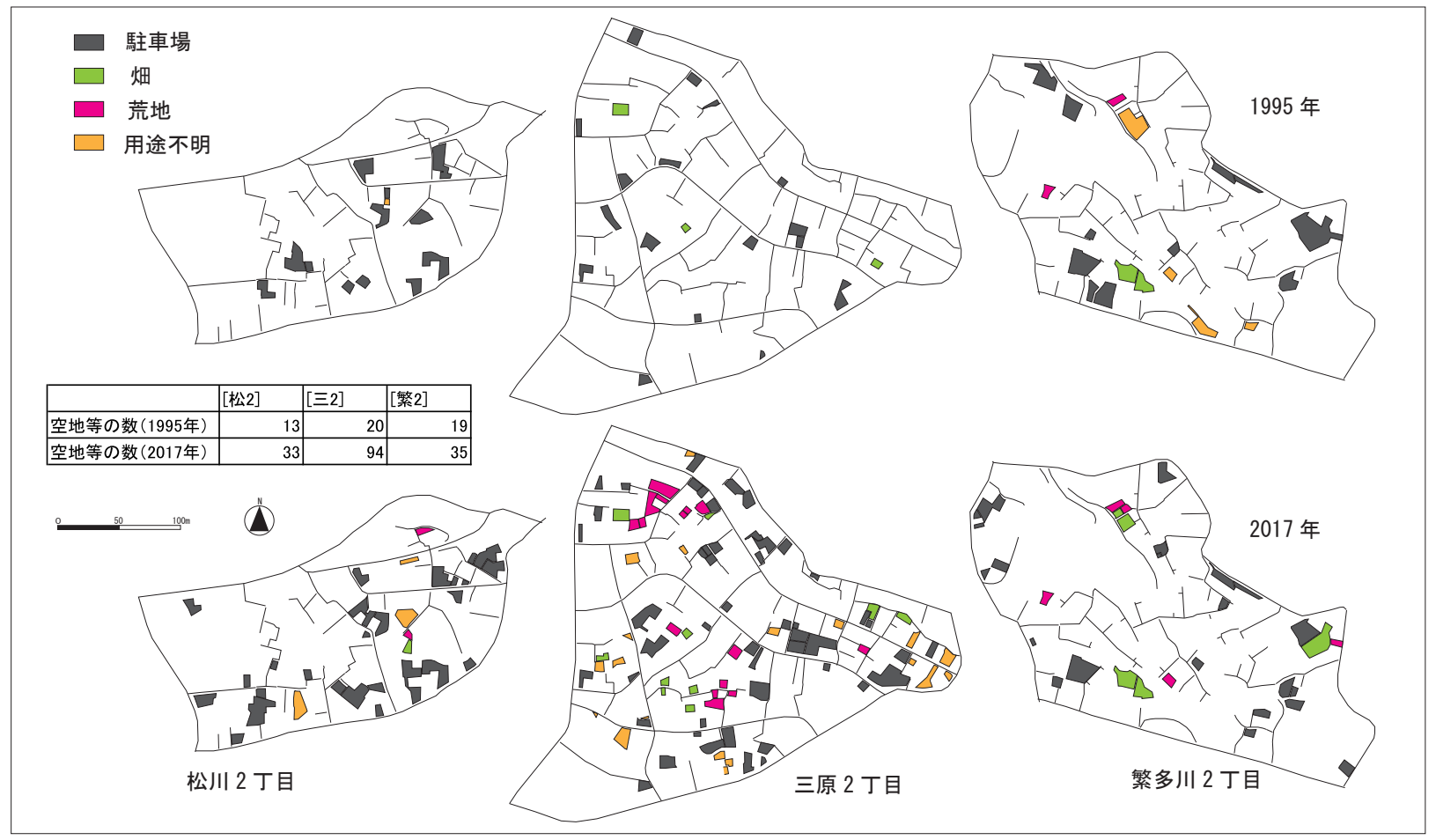

図 3 空き地等の変化 
手法 1 ・緊急避難路利用協定（以下、避難路協定）：緊 急時に民有地を避難路として使用できるよう、民有地の権 利者と行政で協定を締結する。建築物の敷地や空地等を対 象とする。平常は閉じているが緊急時に通過できる非常扉 の設置や案内表示、周囲の住民への通知等を行政が行う。 土地所有者・利用者は避難可能な空間を維持する。東京都 板橋区の事業の先例がある ${ }^{(6)}$ 。

手法 2 ・防災空地整備（以下、防災空地）：空き地や畑 を行政が借り受けるか、避難路としての利用を可能とする 協定により防災空地として確保する。幾つかの制度の先例 があり (7)、防災空地の機能や整備内容は多様なものが考 えられるが、今回は避難経路として通過可能な空間を最低 限確保するものを想定する。先述したとおり、地域の空地 等の状態は流動的な状態で増加しており、防災空地は暫定 的に存在することが想定される。

手法 3 - 緊急避難路形成型協調建替推進（以下、協調建 替)：建築物の新築にあたって、緊急避難路の新設により 地域の避難路の形成に資する建築を推進する。対象は、緊 急避難路の確保により地域の避難路形成に資する可能性 のある敷地、寸なわち、既存の避難経路をつなぐ位置にあ るものとし、小規模宅地は避難路確保の負担が大きいと考 え $150 \mathrm{~m}^{2}$ 以上の敷地を想定する ${ }^{(8)}$ 。具体的な誘導・規制 内容としては、(1)隣地境界から $1 \mathrm{~m}$ セットバックするなど、 幅 $1 \mathrm{~m}$ 以上の緊急避難路の空間を敷地内に確保する、(2)緊 急避難路に手法 1 と同様の非常扉を設ける、ことを条件と して想定する。実施方法としては、規制的方法、あるいは 何らかのインセンティブによる誘導等が考えられる。
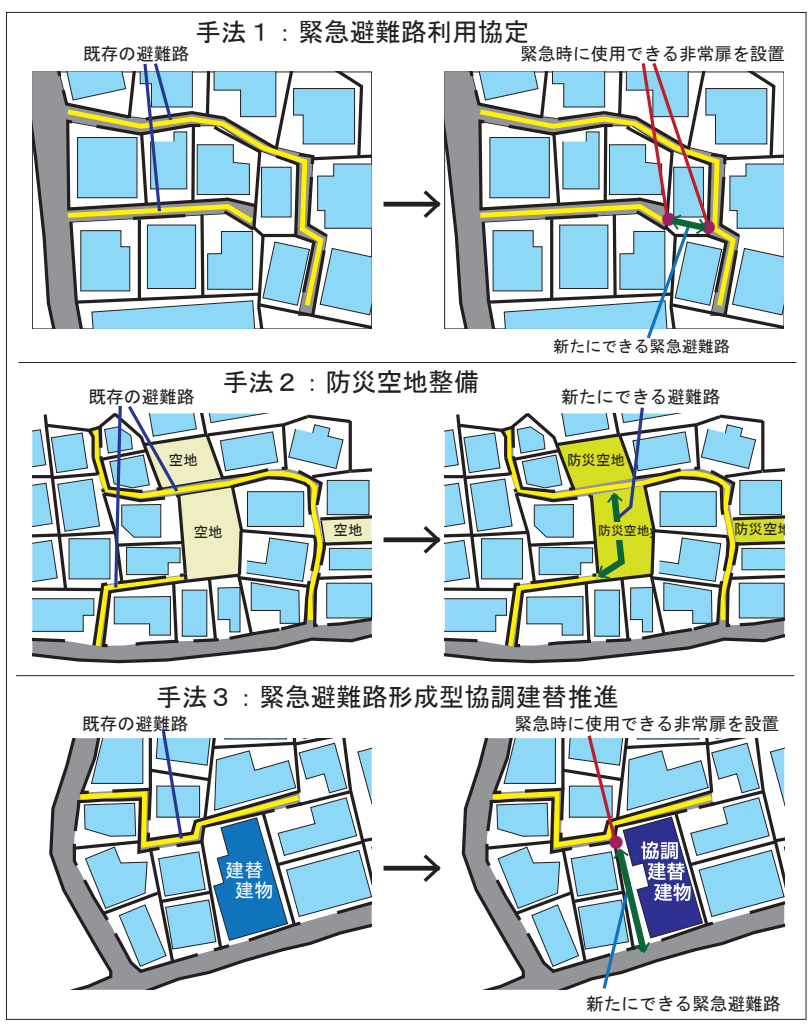

図 4 避難路の改善手法（模式図）

\section{6. 各手法による避難路の改善の可能性}

\section{1 検討の方法}

各手法による地域の避難路の改善可能性を検討した。

本研究で検討するのは、敷地の位置関係、建物の形態等 による物理的可能性である。実際の合意形成に関わる社会 的可能性は本研究の次段階の課題となる。

手法 1 (避難路協定) を適用可能な敷地は、調查時点 (2018 年 10 月）に協定によって有効な緊急避難路が生じる位置 に敷地があり、敷地内に幅 $1 \mathrm{~m}$ 程度以上の通過できる空間 があること、周囲との段差が $1.5 \mathrm{~m}$ 以下であり地形的に困 難な条件がないこと、を条件とした。避難路協定を適用可 能と考えられる敷地を地図上の検討と現地確認により選定 した。

手法 2 (防災空地）を適用可能な宅地は、調査時点の空 地等の中で火災時の問題が想定される駐車場を除き、利用 されていない空地（用途不明、荒地）および緊急時の避難 経路とすることが両立可能と考えられる烟とした。

手法 3 (協調建替) は近い将来に建築更新の可能性があ る土地を選定することは困難であるので、過去 20 年（1998 ～ 2017 年度の建築確認による）（9）に新築された建築物敷 地一の適用とした。すなわち、20 年前に制度適用が開始 されたと仮定した場合に実現した可能性がある緊急避難路 を把握することとした。前述のとおり、狭小宅地を除き、 緊急避難路形成に貢献可能な位置にある新築建物の敷地を 取り出した。

\section{2 改善手法を単独に適用した場合}

各手法を各々単独に適用した場合の改善可能性を検討し た。適用可能性があると判断した箇所の数は表 1 の通りで ある。

避難路協定を適用可能と判断される箇所は他の手法より 多く見出された。防災空地となりえる場所は空地等が急増 している [三2］で特に多い。協調建替は、全体で 90 棟 の新築（敷地面積 $150 \mathrm{~m}^{2}$ 以上）がある中で、既存避難路を つなぐ位置にあり緊急避難路形成に資する可能性のあるも のは各地区で 2 件ずつにとどまった。

以上の手法が適用できた場合を仮定し、3つの評価指標 ごとの地域の避難路の状況の改善を検討した。各手法の適 用により既存の避難路に緊急避難路が加わり、各建物から の避難路が増える場合がある。全建物（計 1232）からの 避難路を手法適用の場合ごとに確認し、避難路の状況ごと の建物数を単位として、指標ごとの評価を集計した（図 5 )。

なお、手法 2 (防災空地) の適用の場合の評価は、防災 空地が既存避難路と合わせて避難経路の一部として機能寸

\section{表 1 改善手法の単独適用により想定される改善箇所}

\begin{tabular}{|l|r|r|r|}
\hline & [松2] & [三2] & [繁2] \\
\hline 建物数 & 304 & 577 & 351 \\
\hline 空地等の数 & 33 & 94 & 35 \\
\hline \hline 手法1 (避難路協定)による緊急避難路数 & 19 & 45 & 13 \\
\hline 手法2 (防災空地)による防災空地の数 & 5 & 30 & 13 \\
\hline 手法3(協調建替)による緊急避難路数 & 2 & 2 & 2 \\
\hline
\end{tabular}


ると考えるが、防災空地に直接接する建物からの避難は手 法 1 の適用による避難口が設置された段階ではじめて可能 になるものと判断した。

指標 1 （幅員）は、いずれの手法、いずれの地区におい ても、わずかな改善に留まる。避難路の最低幅員が $2 \mathrm{~m}$ 末 満から $2 \mathrm{~m}$ 以上あるいは $4 \mathrm{~m}$ 以上に改善されたものは各地 区とも $1 \%$ 程度以下である。各手法により新しく生まれる 避難路の多くが既存の狭い避難路であるため、この指標の 改善にはつながりにくいと考えられる。

指標 2 （木造・非木造）については、地区ごとの改善 の差がみられる。[松 2］［三2］では、指標 1 に比べて 若干改善される建物が多い程度だが、[繁 2] では手法 1 （避難路協定）によって避難路沿いに木造建物があるもの が 21.7\% から 11.4\% に減少する。[三 2 ] は木造建物の割 合が $36.7 \%$ と高いため、避難路が増えても避難路沿いに木 造建物がある状況があまり変わらないことが一因と考えら れる。[松 2］と［繁 2］の木造建物率は比較的低いにも かかわらず改善割合が異なるのは、[松 2] の木造建物が 比較的地区内全体に分散しているのに対して、[繁2] は 経路沿いに木造建物が多い避難路と木造建物がない避難路 （多くは位置指定道路）が混在しており、いくつかの木造 建物のない避難路への緊急避難路が通じた時点で状況が改 善する例が複数みられたためである（図 8)。

指標 3 (二方向) は、三つの指標の中で手法 1 (避難路 協定）による改善割合が 3 地区とも最も高い（図 5 )。[松 2] の場合を図 6 の中段に示す。手法 1 は避難路の選択肢 を増や寸手法であるため、全ての想定箇所での緊急避難路 協定が実現すれば、避難路が一方向のみの建物が各地区で 約半数になる可能性がある。

\section{3 改善手法を組み合わせて適用した場合}

手法 $1 、 2 、 3$ を組み合わせて適用した場合の避難路の 改善状況を検討した。手法 $2+3$ の場合は、適用箇所が少な いために単独の場合とほぼ効果は変わらない。手法 $1+2$ 、 手法 $1+3$ は単独の場合よりも指標の改善度合が大きくな る。以下、とくに手法 $1+2+3$ の組合せ適用について各指標 の変化を記し（図 5 )、改善の状況の例を図 6 ～8 に示寸。

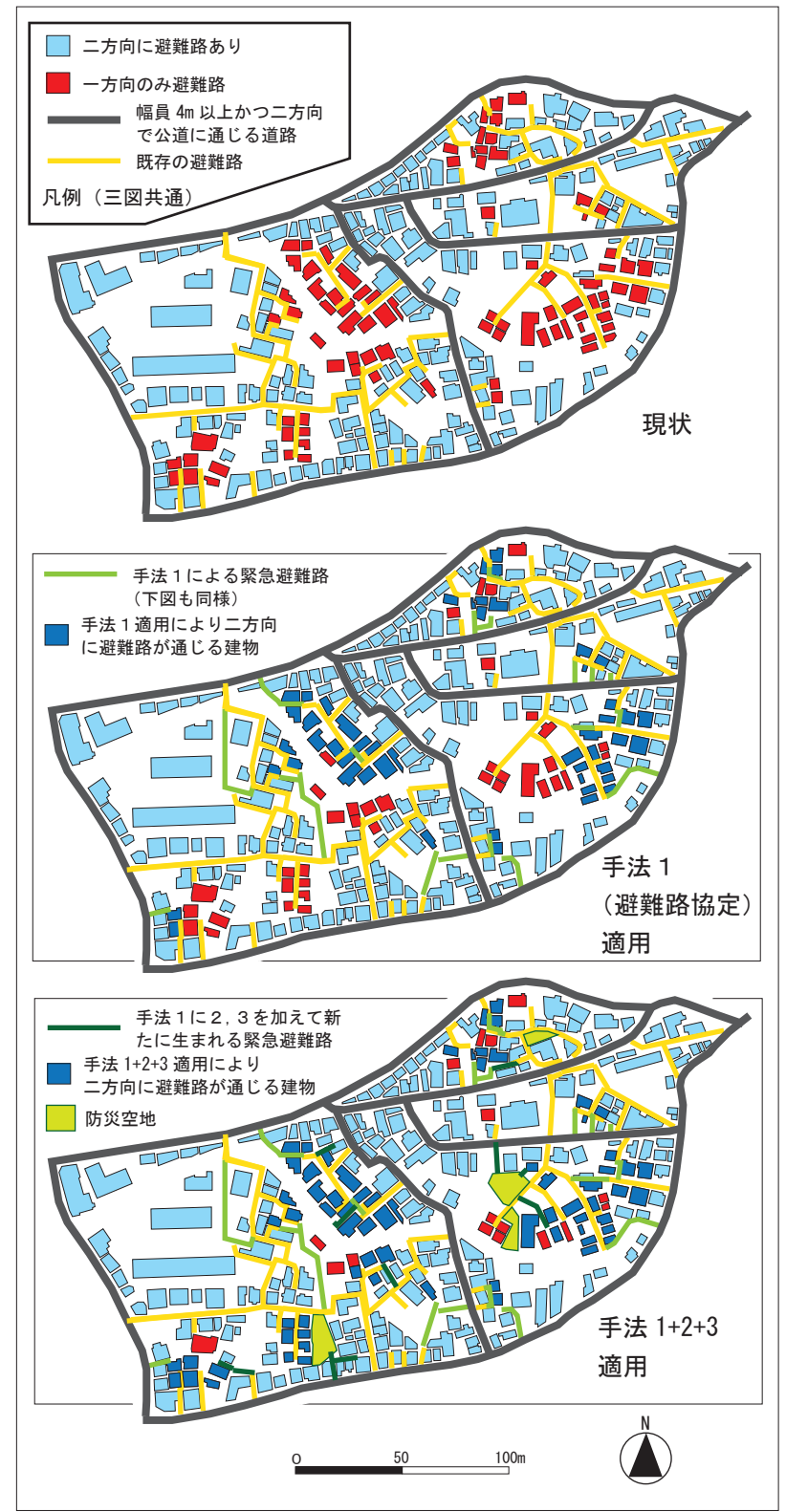

図 6 手法 1 および組合せ適用による避難路の改善 (指標 3 (二方向)、[松 2] の場合)

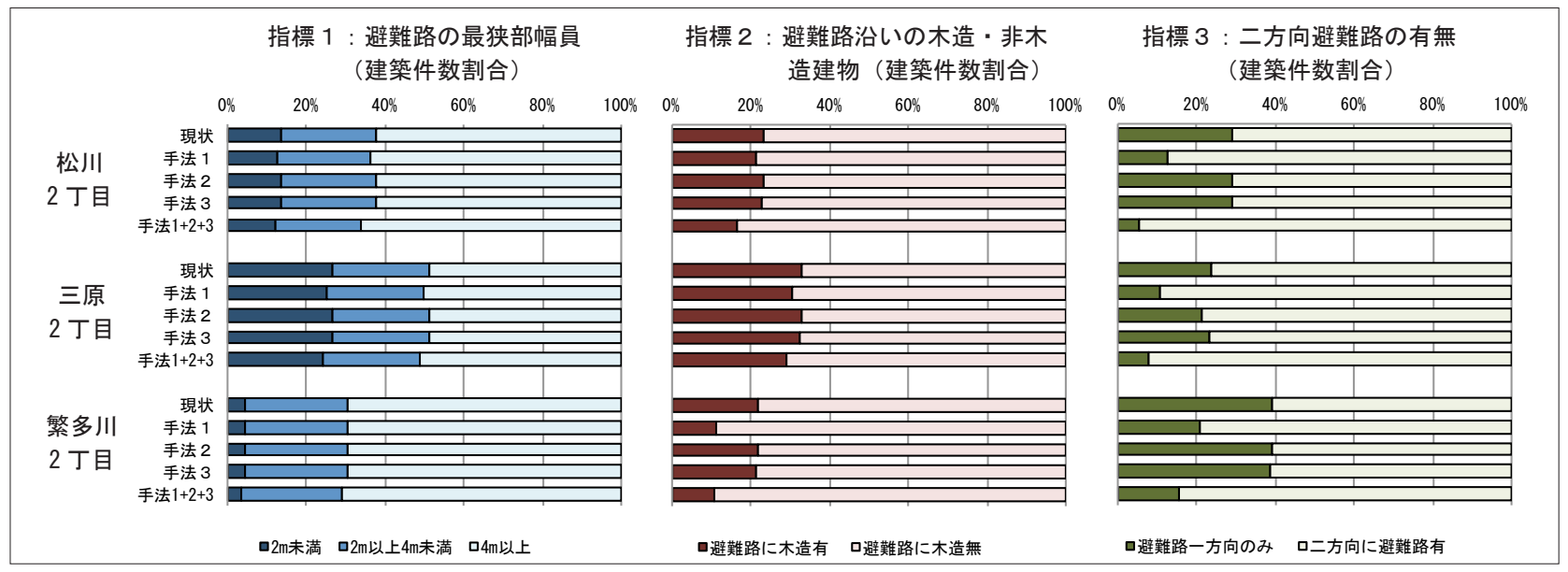

図 5 各改善手法および組合せ適用による避難路の改善 
［松 2］の指標 2 は、避難路に木造建物があるものが手 法 1 のみで $21.4 \%$ から 3 つの組合せで $16.4 \%$ に減少する(図 5 )。[松 2 ] の指標 3 は、二方向避難路無しが手法 1 （避 難路協定）の久で $12.5 \%$ から手法 1+2+3 の組合せで $5.6 \%$ に減少する（図 5、図 6)。他の 2 地区は［松 2］ほどの 違いはないが、とくに指標 3 （二方向）は組合せ適用によ る改善がみられる(図 5 、図 7 )。

手法の組合せによる効果の要因は次のものが考えられる (図6、図 7 、図 8)。

(1)手法 2 （防災空地）は単独適用の場合は既存避難路の空 間拡大の意味にとどまるが、手法 1 （避難路協定）との組 合せで防災空地に接する宅地からの避難口が設定でき、避 難路の選択肢が増える、

(2)手法 3 (協調建替) は単独適用の場合は効果的な位置に あるものが少数しか見いだせないが、手法 1 (避難路協定) の既存建物内の緊急避難路、手法 2 (防災空地) の両方之 つながることで、協調建替によって生まれる緊急避難路が 既存避難路につながる可能性が増える。

\section{7. 各手法による避難路の改善可能性についての考察 7.1 3つの手法の評価}

手法 1 (避難路協定) が適用された場合の改善の程度が 大きいのは、適用可能性のある空間を全て活用した場合を 想定したためであり、本研究で示したのは避難路の改善に つながる潜在的な可能性である。防犯やプライバシーに関 わる課題もあり合意形成による社会的可能性の検討は次の 段階の課題となる。

手法 2 (防災空地) は現状で通過できるものも含んでお り、現状を生かした方法として実施可能性は比較的高いと 思われる。とくに [三2] のように空地等が増加している 地区での効果が想定できる。荒地化した空地も生じている が、空地の荒廃問題への対策を兼初て防災空地施策を推進 することの必要性も生じている。

手法 3 (協調建替) は、単独では大きな効果を見いだせ なかったが、他の手法との組合せによる効果の可能性が確 認できた。今回の調査地区では大規模な新築建築物や街区 内部の大きな敷地統合による開発などが少数であったが、 大規模な集合住宅や施設などの開発や新築にあたって緊急 避難路の確保が行われれば街区内の避難路の改善につなが る可能性は高いと考えられる。建築の規制・誘導に関わる 手法であるので、住民・地権者の合意形成条件をさらに検 討する必要がある。

手法は単独ではなく、組み合わせて適用寸ることが有効 である。とくに手法 2 (防災空地） と手法 3 (協調建替) を有効に機能させるには、手法 1 (避難路協定) と組み合 わせることが必要である。

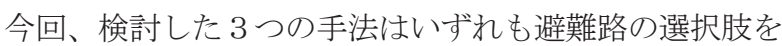
増や寸ものだが、避難路の幅員のように避難路自体の質の 向上には効果が小さい。公的な細街路整備あるいはブロッ ク塀の更新の誘導策などの方法を加える必要がある。

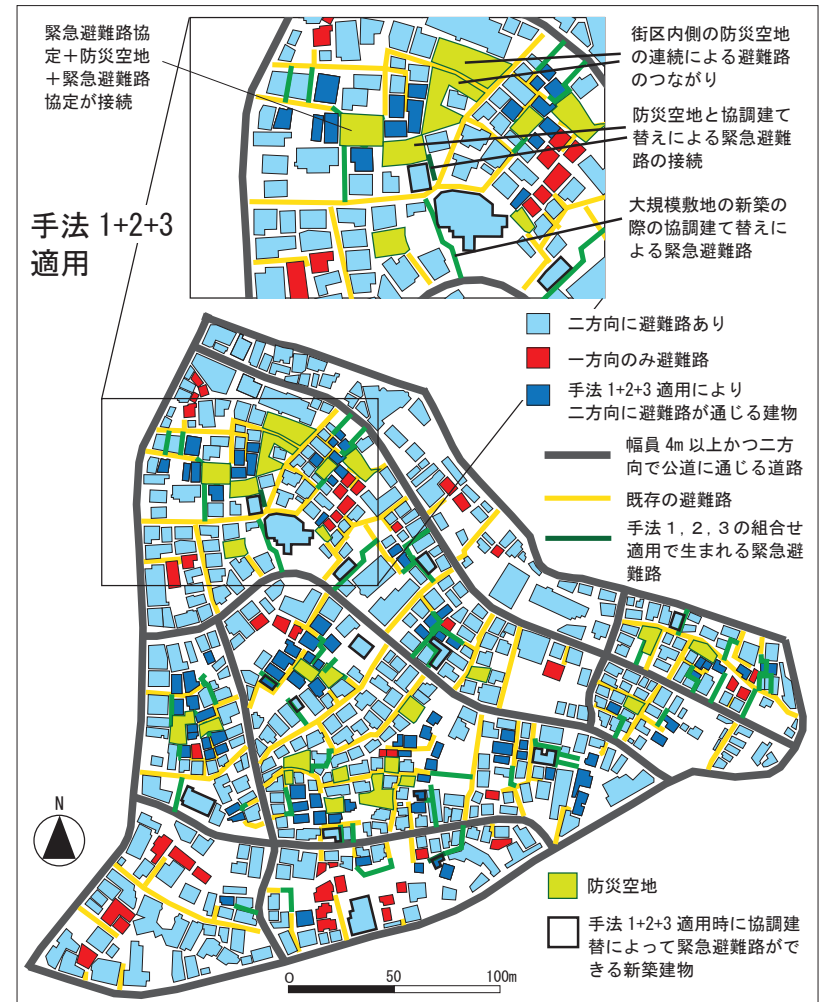

図 7 手法の組合せ適用による避難路の改善の詳細 （指標 3 (二方向)、[三2] の場合）

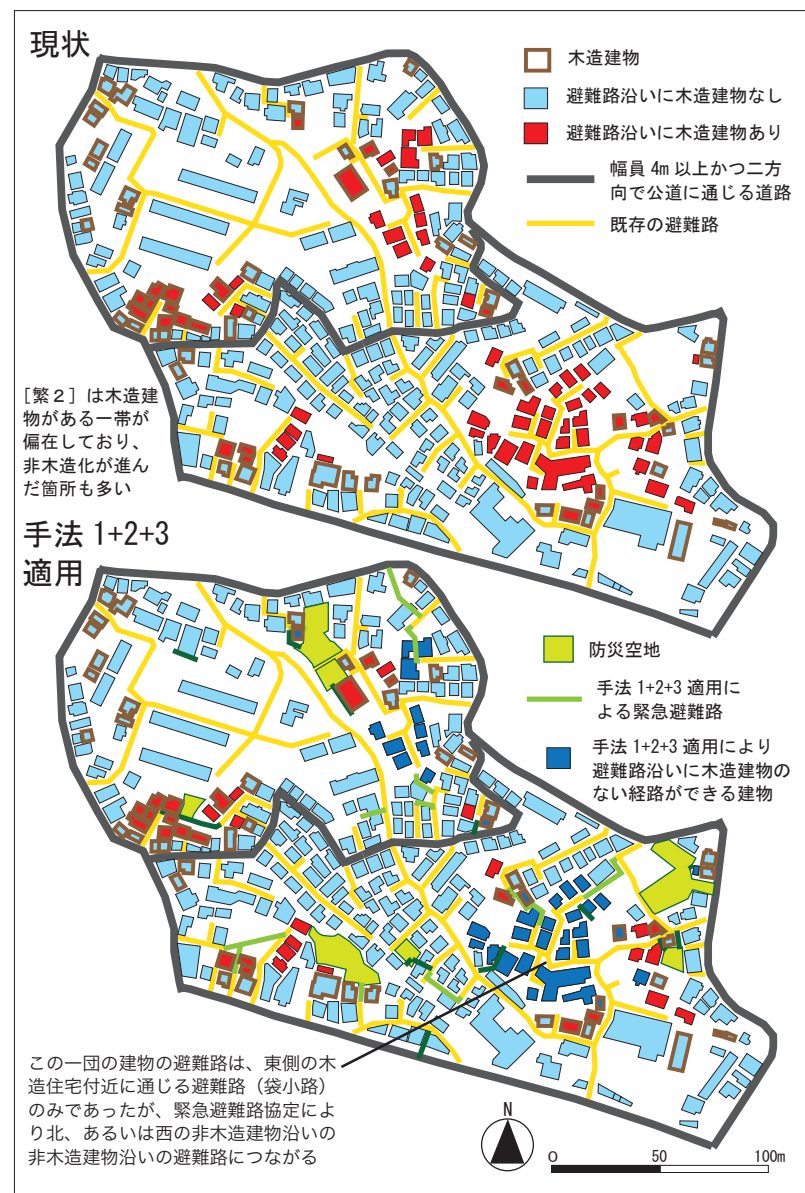

図 8 手法の組合せ適用による避難路の改善 (指標 2 (木造・非木造)、[繁 2] の場合) 


\section{2 行政による施策の可能性}

本研究で設定した手法の実現のためには、民有地内で実 施されることに対して誘導、調整を行う制度の構築が求め られる。

手法 1 (避難路協定)、手法 2 (防災空地）については 先述のとおり実施例がある。

手法 3 (協調建替）については、協調建替を建築の新た な制限・誘導の仕組みとして導入するには、地域における 合意形成の可能性を慎重に検討する必要がある。地区計画 のように面的で拘束力の強い方法、インセンティブを伴う 方法、建築協定や任意協定などの地権者の活動として進め る方法など、実現方法の多面的検討が必要である。

また、手法 1 （避難路協定）に関連して地域の公有地や 公共施設について緊急避難路協定の主体として公共団体が 率先して進めるという方法も考えられる。那覇市の密集市 街地には学校や公営住宅団地が街区の内側に立地している 例があり、避難路整備に貢献する可能性がある。

一方、図 6〜8で確認されるように、民有地内の空間活 用により改善されない場所も多く存在している。公的な整 備との併用による総合的な改善策が求められる。本研究の 方法は、行政による重点的整備が特に必要な箇所の抽出の 方法としても有効と考えられる。

\section{3 地域住民、コミュニティによる取り組みの可能性}

3つの手法の実現には公的制度を構筑することが望まし いが、地域組織の取り組みの例 ${ }^{(10)}$ があるように、地域住 民、コミュニティの取り組みとしても改善に取り組める可 能性がある。

とくに地域において支援を要する住民のサポートなどと 合わせて緊急時の避難・救助路を検討することは地域の福 祉関係者、自治会等の課題となっている可能性があり、本 研究のスタディに相当する資料をもととして、地域住民に よる自主調查や可能性の検討、相互調整などを行うことが 考えられる(11)。

\section{8. まとめ}

沖縄県内の密集市街地特有の状況にある那覇市の密集市 街地において、調查対象地区における避難路の改善可能性 を、主に民有地を活用する手法について、設定した指標に 沿って示すことができた。

設定した三手法を組み合わせて適用することにより、と くに二方向への避難可能な建物を増やせる可能性がある。 本研究の知見は公的な事業・制度の検討の手掛りとする とともに、地域住民による自主的検討の題材としての活用、 民有地を活用する手法で限界のある地区での公的改善手法 の検討へとつなげることが考えられる。

\section{謝辞}

本研究の実施にあたり、共同検討の機会をいただいた那 覇市繁多川地域の関係者（繁多川公民館、繁多川自治会他) と那覇市まちなみ整備課の皆さまに謝意を表します。

\section{注釈}

（1）那覇市は「那覇市住宅密集市街地再生方針」（2016 年 3 月）で 密集市街地再生の大まかな方向を示している。

（2）図 2 の道路種別は、「那覇市道路種別マップ」（那覇市がサイト 上で公開）により、現地確認で存在しないものを除いた。

（3）「ゼンリン住宅地図」1995 年版、2017 年版による。2017 年の状 況は現地での確認を加えた。

(4) 街区の外側には既に幅員 $4 \mathrm{~m}$ 以上で二方向に通じた道路に接し ている敷地があり、それらは避難路無しとなるが、評価にあたつ ては、各指標において、幅員 $4 \mathrm{~m}$ 以上、避難路に木造無、二方向 に避難路有として評価して集計に含めている。

（5）「一寺言問を防災のまちにする会」（東京都墨田区）による取り 組みとして知られている(http://hitokotokai. com 2019/4/23 閲覧)

（6）板橋区「行き止まり道路の緊急避難路整備事業」（1997～、 2008 年より区内全域で実施)。文献 5 ) 参照

（7）実施している制度の例としては文献 6) 参照。

（8）良好な住宅地における宅地規模と考えられている水準として沖 䋲県内の地区計画での最低敷地規模を参照して設定した。

（9）1998～2017 年度の建築確認により、2018 年 10 月までに新築さ れたものであるので、1998〜 2017 年度より少し遅れた約 20 年間 に竣工したものとなる。建築計画概要書にあるもので、現地に新 築後の建物が存在しているものを調查で確認した。

(10) 注（5）と同じ

（11）筆者らは、本研究の作業と並行して、避難路の実態と課題、改 善方法について、現地調查と改善可能性の検討を地域住民や関係 機関と共同で行う活動を継続してきた。取り組みの一部を文献 8) にて紹介している。

\section{参考文献}

1）金子弘・勝又済・岩見達也・西澤繁毅（2017），「密集市街地に おける協調的建て替えルールの策定支援技術の開発」，国総研資料 第 928 号，国土交通省国土技術政策総合研究所

$2 ）$ 鶴谷一貴・赤崎弘平（2010），「密集市街地における路地を活か したまちづくりの導入に関する研究」, 都市計画論文集, Vol. 45 No. 3, pp. 1-6, 日本都市計画学会

3 ）加島鈴乃・小野尋子（2017），「戦後に形成された沖縄の密集市 街地の課題と特徴に関する研究 一沖縄県那覇市真和志地域を対 象にしてー」, 日本建築学会計画系論文集, 第 82 巻 第 731 号, pp. 116-122, 日本建築学会

4 ）飯島緑・真野洋介 (2009), 「木造密集市街地の災害時避難リス ク集積エリアの環境把握と改善方針の検討」, 都市計画論文集, Vol. 44 No. 3, pp. 283-238, 日本都市計画学会

5 ）櫻井大州・宇於㠃勝也（2014）,「木造密集市街地における緊急避 難路の確保に関する研究 一板橋区の『行き止まり道路の緊急避難 路整備事業』をもとに一」, pp. 85-86, 日本建築学会学術講演梗概集, 2014 年度, 日本建築学会

6 ）三好章太・嘉名光市・佐久間康富（2017），「密集市街地の民有 地を暫定利用する防災空地の評価指標の検討 一神戸市『まちな か防災空地整備事業』を対象として一」, 都市計画論文集, Vol. 52 No. 3, pp. 293-300, 日本都市計画学会

7 ）湯川恭平・中田幸造（2018），「沖縄県における既存コンクリー トブロック塀の構造実態に関する調查研究」, 2018 年度日本建築学 会九州支部研究報告集, pp. 189-192, 日本建築学会

8 ）松島啓信・清水肇（2018），「沖縄における密集市街地の改善プ ロセスの検討 住民参画による避難路検討ワークショップを通し て」, 日本建築学会学術講演梗概集, 2018 年度, pp. 347-348, 日本 建築学会 